\title{
Characterization of Household Solid Wastes in the Niger Delta: A Case Study of 100-Domestic Units in Yenagoa Metropolis, Nigeria
}

\author{
Tariwari Chidi Angaye", Chidinma Daokoru-Olukole, Jasper Freeborn Nestor Abowei \\ Department of Biological Science, Faculty of Science, Niger Delta University, Amassoma Wilberforce Island, Nigeria \\ Email address: \\ maktarry@yahoo.com (T. C. Angaye) \\ ${ }^{*}$ Corresponding author
}

\section{To cite this article:}

Tariwari Chidi Angaye, Chidinma Daokoru-Olukole, Jasper Nestor Abowei. Characterization of Household Solid Wastes in the Niger Delta: A Case Study of 100-Domestic Units in Yenagoa Metropolis, Nigeria. International Journal of Sustainable Development Research. Vol. 3, No. 5, 2017, pp. 50-53. doi: 10.11648/j.ijsdr.20170305.12

Received: September 22, 2017; Accepted: October 10, 2017; Published: November 10, 2017

\begin{abstract}
Household solid waste (HSW) stream is becoming problematic due to the threat they posed to the environment and public health. Application of inefficient and insufficient management strategies results in unsegregated HSW which are burnt, or left to undergo biological or physicochemical transformation which affects the atmospheric ambient air quality of the environment. In this study, waste streams were characterized in a block multi-stage and stratified randomized post-monthly study, comprising of 100-domestic unit. Comparatively, the mass composition of garbage (food) waste streams was $211.50 \mathrm{~kg}$ $(40.82 \%)$ in dry season, and $285.70 \mathrm{~kg}(42.81 \%)$ in wet season. Plastic/rubber wastes, had values of $127.00 \mathrm{~kg}(24.51 \%)$ and $138.01 \mathrm{~kg}(20.68 \%)$ in dry and wet seasons respectively. Similarly, paper waste stream was $70.30 \mathrm{~kg}(13.56 \%)$ in dry season and $98.41 \mathrm{~kg}(1476.68 \%)$ in wet season. Furthermore, glass/ceramic waste had seasonal values of $56.20 \mathrm{~kg}$ (10.85\%) for dry season and $62.59 \mathrm{~kg}(9.37 \%)$ for wet season. Furthermore, the composition of metal and wood waste streams per 100 domestic units in dry/wet season were reported as; $29.50 \mathrm{~kg}(5.70 \%) / 39.40(5.90 \%)$ for metals; and $12.70 \mathrm{~kg}(2.45 \%) / 24.23(3.63 \%)$ for wood. Other unclassified and special wastes streams which includes but not limited to ashes, sand, stones, clothes were reported to have values of $10.90 \mathrm{~kg}(2.10 \%)$ in dry season and $19.00 \mathrm{~kg}(2.85 \%)$ in wet season. Disposal of uncharacterized HSW is hazardous and pose grave consequences to the environment, we therefore urge the populace to desist from reckless disposal of HSWs and also urge Government to formulate policies the will enhance safe disposal of wastes for the effective reuse and recycling.
\end{abstract}

Keywords: Waste Stream, Anthropogenic Activity, Municipal Solid Waste, Yenagoa Metropolis

\section{Introduction}

The problems posed by improper and ineffective management of Municipal Solid Wastes/Household Solid Wastes (HSW/MSWs) has become an issue of global concern over the past decades. The magnitude of waste stream has acquired some abrupt dimensions [1,2], with corresponding ineffective and inadequate management strategies [3, 4], including insufficient funding on the part of Government [5, 6]. The incidence of poor waste handling that has infringed on vital environmental components; including but not limited to soil, water and to air quality. Also, the magnitude of commercialization, industrialization and population expansion of most cities all over the world has also had its attendant adverse effects on the environment due to poor ameliorative strategies [7,8].

A previous study on MSWs streams in Nigeria, showed that waste stream densities ranges from ranges from 280 $370 \mathrm{~kg} / \mathrm{m}^{3}$ [9], with daily rates of about $0.44-0.66$ $\mathrm{kg} /$ capital/day, resulting to an annual generation of 25 million tons [10]. Furthermore, Nigerian urban population density has witnessed an abrupt rise due to rural-urban migration, largely necessitated by yearning of the populace to keep abreast or understand contemporary technological 
applications [11]. Unfortunately, high population density is implicated the generation of large waste streams, with inadequate facilities and consequently results to environmental pollution. As such industrialization and population expansion seems to have resulted in the generation of large waste streams [12]. In most developing countries, anthropogenic activities associated with the precarious disposal of MSWs poses more grave consequences to the ecosystem, besides being threat to public health [13].

In most developing country waste streams are generated with inadequate funding of the sector by Government coupled with poor sensitization of the populace on the dangers posed by precarious handling of MSWs, as well as weak legislation to deter erring persons. When waste is dumped precariously recklessly, they undergo certain transformation over time produce to foul odour and toxic leachates that impair air quality and other fragile components of the ecosystem including water and soil [14], as well as other aquatic and terrestrial biota by the process of bioaccumulation [8]. Another aspect of environmental pollution arising from Solid Wastes is the practice of in-situ combustion of unsegregated waste stream (especially in the dry season), which produce toxic pollutant gases with envisaged greenhouse effects. Consequent upon the danger posed by these anthropogenic activities; the Characterization of HSWs and it seasonal impact is hereby investigated.

\section{Method}

\section{Study Area}

The study area is Yenagoa Metropolis which is the capital city in Bayelsa State, Nigeria. Bayelsa state lies central and southernmost on the Nigerian Map. Yenagoa is located on latitude $4^{\circ} 49 \mathrm{~N}$ and $5^{\circ} 23^{\prime} \mathrm{N}$ and longitude $6^{\circ}$ $10^{\prime} \mathrm{E}$ and $6^{\circ} 33^{\prime} \mathrm{E}$ with a population estimate of over 300,000 [15]. Since attaining the status of a state capital in 1996 its urbanization and population density have since accelerated appreciably. Yenagoa forms part of the wetland characterized by shallow aquifer and several networks of creeklets linked to a parent creek called Epie Creek. Consequently, the major river which connects all Municipal runoffs is the Epie Creek, which basically empties into the Nun River, which lies central and flanked to the west and East by Rivers Focardos (Delta State) and Orashi (Rivers State) respectively.

\section{Waste Characterization}

Multi-stage stratified random sampling was used with slight modification [16]. A total of 100 domestic units consisting of a four-block area of 25 unit each (Edepie, Opolo, Biogbolo and Amarata), were randomly selected for the survey. Each selected domestic unit was visited bi-weekly in a post-monthly manner in order to assess the mass and volume of waste stream generated, with core reference to season (November-March for dry season and April - October for wet season).
Prior to the survey, field assistants/volunteers were trained, recognisance and consent visits were ensured in order to sensitize the volunteers of the study units. About A 50 litres of cylindrical plastic container with waterproof bags inserted was provided to each study units for the collection of HSWs streams, volume of the waste was determined based on the shape of the waste container $\left(V=\pi r^{2} h\right)$. The wastes stream were weighed before sorting them out to their various components (i.e. garbage, plastic/rubber, metal, glass/ceramics, wood and other which includes but not limited to special waste like ashes).

Statistical Analysis

All data were expressed as mean using version 20 of SPSS statistical package. Microsoft excel was used to plot graph from derived mean values.

\section{Results}

As presented in Figure 1, the seasonal mass composition of waste streams in study area indicated that garbage (food) waste streams $(479.20 \mathrm{~kg})$, are composed of $211.50 \mathrm{~kg}(40.82 \%)$ in dry season, and $285.70 \mathrm{~kg}(42.81 \%)$ in wet season per 100 domestic unit. Plastic/rubber wastes, with total mass of $265.01 \mathrm{~kg}$ per 100 domestic unit had individual seasonal values of $127.00 \mathrm{~kg}(24.51 \%)$ and $138.01 \mathrm{~kg}(20.68 \%)$ in both dry and wet seasons respectively. The mass of paper waste stream per 100 domestic unit was $168.81 \mathrm{~kg}$, with seasonal values of $70.30 \mathrm{~kg}(13.56 \%)$ and $98.41 \mathrm{~kg}(1476.68 \%)$ in dry and wet season respectively. Furthermore, glass/ceramic waste streams having total mass of $118.76 \mathrm{~kg}$ per 100 domestic unit, had seasonal values of $56.20 \mathrm{~kg}(10.85 \%)$ for dry season and $62.59 \mathrm{~kg}(9.37 \%)$ for wet season. Furthermore, the seasonal composition of metal and wood waste streams per 100 domestic units in dry/wet season were reported as; $29.50 \mathrm{~kg}(5.70 \%) / 39.40(5.90 \%)$ for metals; and $12.70 \mathrm{~kg}(2.45 \%) / 24.23(3.63 \%)$ for wood. Other unclassified and special wastes streams which includes but not limited to ashes, sand, stones, clothes were reported to have values of $10.90 \mathrm{~kg}(2.10 \%)$ in dry season and $19.00 \mathrm{~kg}$ $(2.85 \%)$ in wet season.

In this 100-domestic unit, bi-weekly and post-monthly investigation, the seasonal net value of waste streams in wet season was $518.10 \mathrm{~kg}(43.71 \%)$ having a volume of $290.50 \mathrm{~m}^{3}$, compared to a higher value for wet season with $667.30 \mathrm{~kg}(56.29 \%)$ and a volume of $329.80 \mathrm{~m}^{3}$. Furthermore, the cumulative net mass of waste stream per 100 domestic unit was $1185.40 \mathrm{~kg}$ with volume of $620.30 \mathrm{~m}^{3}$. Furthermore, the net mass of organic waste streams in the study area was $931.03 \mathrm{~kg}$ per 100 domestic unit with individual seasonal values of $408.80 \mathrm{~kg}$ in dry season compared to $522.22 \mathrm{~kg}$ in wet season. Comparatively, the inorganic waste stream had net weight of $254.52 \mathrm{~kg}$, with seasonal values of 109.30 and $145.22 \mathrm{~kg}$ in dry and wet seasons per 100 domestic unit, respectively. Furthermore, it can be estimated that Yenagoa metropolis generates an annual waste stream with net mass of $4741.60 \mathrm{~kg}$ with volume of $2481.20 \mathrm{~m}^{3}$ per 100 domestic unit. 


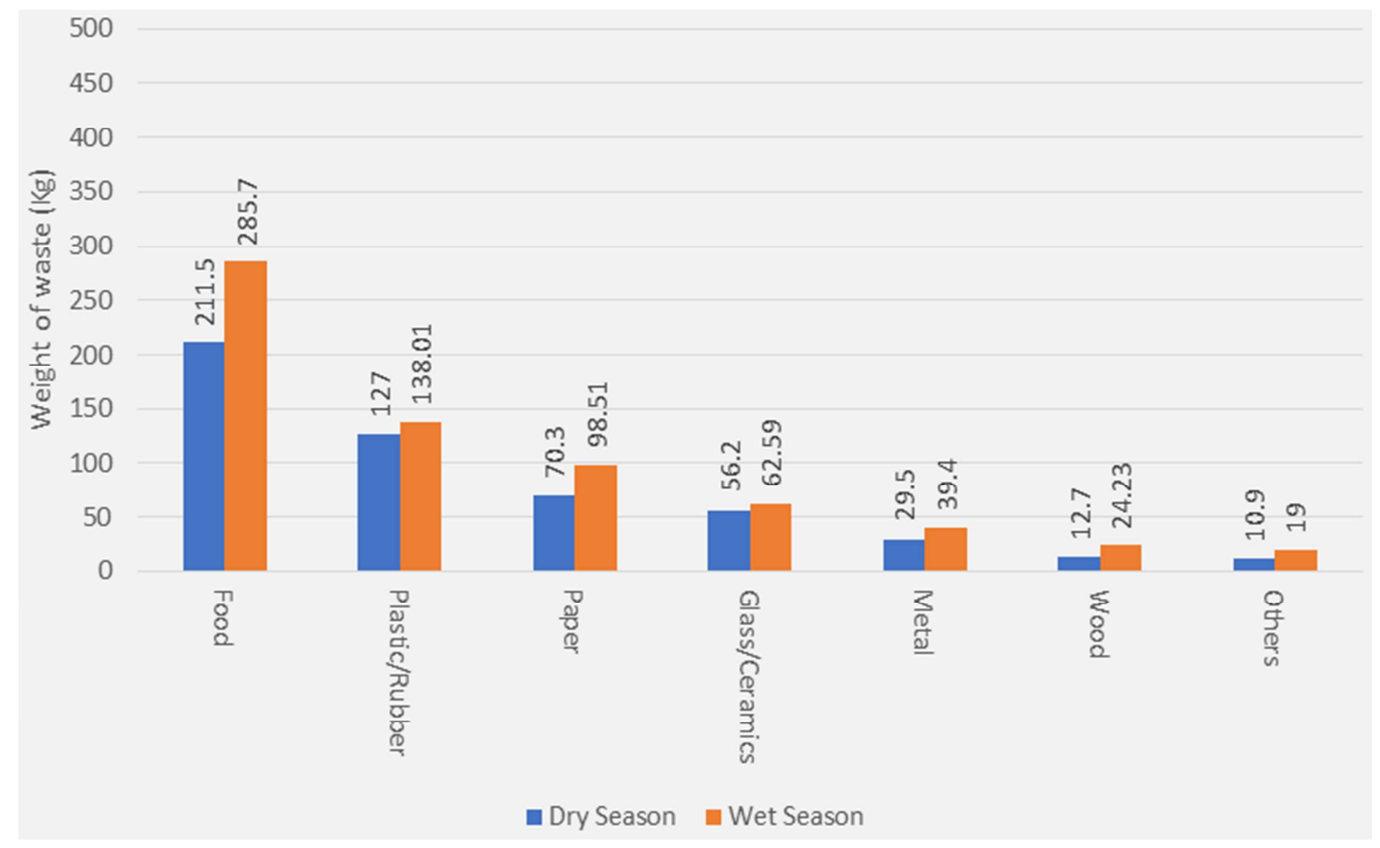

Figure 1. Characterization of Municipal Solid Waste in Yenagoa Metropolis.

\section{Discussions}

An investigation on the characterization of MSWs in Abuja metropolis recorded the following; Garbage $(56.20 \%$ dry season and $52.0 \%$ wet season), of the solid waste generated in the area rubber (dry season $10.20 \%$ and wet season $3.56 \%$ ); paper (wet season $10.00 \%$ and dry season $12.46 \%$ ), glass/ceramics (dry season $7.60 \%$ and wet season $1.42 \%)$ plastics $(7.4 \%$ and $2.85 \%)$, metals $(2.60 \%$ and $0.71 \%$ ) and other forms of MSW which includes dust particle, ash, stones was $5.60 \%$ in dry season and $25.62 \%$ in wet season [7].

Another study on characterization of MSWs in Benin metropolis recorded a total waste stream of $2323.93 \mathrm{~kg}$; with individual component, as: $44.96 \%$ garbage, $25.43 \%$ plastic, $14.27 \%$ paper, $3.21 \%$ metal, $3.89 \%$ glass, and $8.24 \%$ for other wastes which includes but not limited to ceramics, foam, clothes. Waste stream like nylon was reported to be high due to commercial activities in Benin metropolis [16]. Furthermore, our recent finding is also comparable to the investigation of Musa et al., [17], in Kazaure LGA of Jigawa state with daily generation per capita volume as $0.85 \times 10^{-3}$ and $0.88 \times 10^{-3} \mathrm{~m}^{3} /$ person/day in dry and wet seasons. Meanwhile percentages compositions of organic wastes were $53.18 \%$ in dry season and $62.75 \%$ in wet season, compared to inorganic waste of $46.82 \%$ and $37.25 \%$ in dry and wet seasons respectively. Study of MSW in Nsukka of the SouthEast region of Nigeria showed that a total waste stream of $161112 \mathrm{Kg}$ of waste was generated with $42 \%$ as biodegradable waste, while $58 \%$ was reported as nonbiodegradable components [18]. In Uyo, Akwa Ibom state, it is indicated that waste streams ranging from $0.49-0.60$ $\mathrm{kg} /$ capital/day. It comprises of $65 \%$ of compostable materials including; $10 \%$ plastics, $8 \%$ paper, $4 \%$ metal, $3 \%$ textile, $3 \%$ glass and other unclassified waste which makes up 7\% (Okey et al., 2013).

Characterization of HSW/MSW is very intrinsic if waste streams are to be effectively and safely managed in terms of waste recycling. In addition, this will help Government to formulate a policy that will effectively mitigate the adverse effects posed by HSW/MSW [7], especially in the area of waste legislation, treatment and recycling. Unfortunately, this aspect of waste management has been ignored as most municipalities do not know the volume of waste streams generated. It has been documented in literature that in most cases, Government only care for the logistic of gathering and transportation of unsegregated waste which are unsafely dumped outside the municipality, and sometimes burnt to emit toxic gases [16]. Effective recycling, reuse and reduction of waste stream begins from the domestic units and is pictured in proper waste segregation or characterization

\section{Conclusion}

This research investigated the seasonal of characterization and impacts of HSWs on the air quality in Yenagoa metropolis. Consequent upon poor handling of HSW/MSW, they undergo diverse biogeochemical transformation that infringes on sensitive media like ambient air quality. Most landfill systems are composed of unsegregated/characterized wastes streams, which could have been recycled or treated and reused appropriately. Regrettably, most of these uncharacterized wastes are burnt in open air thereby posing grave consequences on the ecosystem, including its biodiversity and greenhouse effects. Unfortunately, our results indicated waste streams in Yenagoa are neither characterized, or treated and even burnt off in open air. This 
study will provide succor to Government and all stakeholders policy in terms of formulating policies for waste inventorization, legislation and sustainable development. Results also showed significant emissions of suspended particulate matter, greenhouse gases like carbon monoxide, hydrogen sulphide and oxides nitrogen.

\section{References}

[1] Schwarz-Herion, O., Omran, A., Rapp, H. P. (2008). A Case Study on Successful Municipal Solid waste management in Industrialized Countries by the example of Karlsruhe City, Germany. Journal of Eng. Annals, 6(3): 266-273.

[2] Amuda, O. S., Adebisi, S. A., Jimoda, L. A., Alade, A. O (2014). Challenges and Possible Panacea to the municipal Solid Wastes Management in Nigeria. Journal of Sustainable Development Studies, 6(1): 64-70.

[3] Angaye, T. C. N., Zige, D. V. and Izah, S. C. (2015). Microbial load and heavy metals properties of leachates from solid wastes dumpsites in the Niger Delta, Nigeria. Journal of Environmental Treatment Techniques, 3(3): 175-180.

[4] Angaye, T. C. N., Angaye W. T., Oyinke G. N., Konmeze O. (2016). Environmental Impact of Scrap Metal Dumpsites on Vegetation, Soil and Groundwater in Yenagoa Metropolis, Nigeria. Journal of Environmental Treatment Techniques. 4(3): 31-36.

[5] Doan, P. L. (1998). Institutionalizing household waste collection: the urban environmental management project in Cote d'Ivoire. Habitat International, 22(1):27-39.

[6] Hossain M. L., Roy Das, S., Talukder, S., Hossain, M. (2014). Generation of Municipal Solid Waste in Commercial City of Bangladesh. Journal of Environmental Treatment Techniques. 2(3): 109-114.

[7] Abur, B. T., Oguche, E. E., Duvuna, G. A. (2014). Characterization of Municipal Solid Waste in the Federal Capital Abuja, Nigeria. Global Journal of Science Frontier Research: Environment \& Earth Science, 14(2): 1-6.

[8] Angaye, T. C. N., Abowei, J. F. N (2017). Review on the Environmental Impacts of Municipal Solid Waste in Nigeria: Challenges and Prospects. Greener Journal of Environmental Health and Public Safety, 2(6): 18-33.

[9] Ayuba, K. A., Abd-Manaf, L., Sabrina A. H., Azmin, S. W. (2013). Current Status of Municipal Solid Waste Management
Practise in FCT Abuja. Research Journal of Environmental and Earth Sciences, 5(6): 295-304.

[10] Ogwuleka, T. C. (2009). Municipal Solid Waste Characteristics and Management in Nigeria. Iran Journal of Environmental Health. 6(3): 173-180.

[11] Adejobi, O. S., Olorunnimbe, R. O. (2012). Challenges of Waste Management and Climate Change in Nigeria: Lagos State Metropolis Experience. African J. Sci. Res. 7(1): 346362 .

[12] Lingan, B. A., Jagadeesh, P. U., Boss, C. (2014). Assessment of Air Pollution and Its Impacts near Municipal Solid Waste Dumping Site Kammiyampet, Cuddalore, India. International Journal of Innovative Research in Science, Engineering and Technology 3(5): 12588-12593.

[13] Adamu, I. M., Dibal, H. I., Duhu, B. Y. (2014). Disposal and Management of Solid Waste in Damaturu, Yobe State, Nigeria: Challenges and Implications. Journal of Environmental Issues and Agriculture in Developing Countries, 6(2): 54-63.

[14] Oyelami, A. C., Aladejana, J. A., Agbede O. O. (2013). Assessment of the impact of open waste dumpsites on groundwater quality: a case study of the Onibu-Eja dumpsite, southwestern Nigeria. Procedia Earth and Planetary Science 7: 648-651.

[15] National Population Census-NCP (2006). Bayelsa State Population Census, National Population Census, Federal Republic of Nigeria.

[16] Igbinomwanhia, D. I (2012). Characterization of Commercial Solid Waste in Benin Metropolis, Nigeria. Journal of Emerging Trends in Engineering and Applied Sciences, 3(5):834-838.

[17] Musa, A. A., Labo, A. S., Lamido, S. M., Salisu, S. A., Ibrahim, M. B., Bello, N. (2016). Characterization of Municipal Solid Waste, In Kazaure Local Government Area, Jigawa State, Nigeria. International journal of Engineering sciences \& research Technology, 5(7): 292-296.

[18] Ugwuishiwu B. O., Nwodo J. C. and Echiegu E. A. (2016). Municipal Solid Waste Characterization in Nsukka Urban in South East Nigeria. Transylvanian Review, 14(7): 808-815.

[19] Okey, E. N., Umana, E. J., Markson, A. A., Okey, P. A. (2013). Municipal Solid Waste Characterization and Management in Uyo, Akwa Ibom State, Nigeria. Transactions on Ecology and the Environment, 173(6): 639-648. 